NBER WORKING PAPER SERIES

\title{
DOES INDIVIDUAL PERFORMANCE AFFECT ENTREPRENEURIAL MOBILITY? EMPIRICAL EVIDENCE FROM THE FINANCIAL ANALYSIS MARKET
}

\author{
Boris Groysberg \\ Ashish Nanda \\ M. Julia Prats \\ Working Paper 13633 \\ http://www.nber.org/papers/w13633 \\ NATIONAL BUREAU OF ECONOMIC RESEARCH \\ 1050 Massachusetts Avenue \\ Cambridge, MA 02138 \\ November 2007
}

We would like to thank George Baker, Adam Brandenburger, Robert Gibbons, Jerry Green, Paul Healy, Josh Lerner, Jackson Nickerson, Nitin Nohria, Thomas Hellmann, Scott Stern, and Ezra Zuckerman as well as participants of the conferences/seminars at 2007 NBER JEMS Entrepreneurship conference, 2007 Utah-BYU Winter Strategy Conference, Columbia Business School, Harvard Business School, MIT, Stanford Business School, and University of Pennsylvania. Our gratitude to professionals at Goldman Sachs, Institutional Investor magazine, Lehman Brothers, Merrill Lynch, and Sanford C. Bernstein for interviews and comments on previous drafts. We also wish to thank Kathleen Ryan and James Schorr for research assistance. We gratefully acknowledge the Division of Research at the Harvard Business School for providing financial support for this study. The views expressed herein are those of the author(s) and do not necessarily reflect the views of the National Bureau of Economic Research.

(C) 2007 by Boris Groysberg, Ashish Nanda, and M. Julia Prats. All rights reserved. Short sections of text, not to exceed two paragraphs, may be quoted without explicit permission provided that full credit, including $\odot$ notice, is given to the source. 
Does Individual Performance Affect Entrepreneurial Mobility? Empirical Evidence from the Financial Analysis Market

Boris Groysberg, Ashish Nanda, and M. Julia Prats

NBER Working Paper No. 13633

November 2007

JEL No. J24,J4,J6,J63

\begin{abstract}
Our paper contributes to the studies on the relationship between workers' human capital and their decision to become self-employed as well as their probability to survive as entrepreneurs. Analysis from a panel data set of research analysts in investment banks over 1988-1996 reveals that star analysts are more likely than non-star analysts to become entrepreneurs. Furthermore, we find that ventures started by star analysts have a higher probability of survival than ventures established by non-star analysts. Extending traditional theories of entrepreneurship and labor mobility, our results also suggest that drivers of turnover vary by destination: (a) turnover to entrepreneurship and (b) other turnover. In contrast to turnover to entrepreneurship, star analysts are less likely to move to other firms than non-star analysts.
\end{abstract}

Boris Groysberg

Harvard University

Morgan Hall 331

Soldiers Field Road

Boston, MA 02163

bgroysberg@hbs.edu

Ashish Nanda

Harvard Law School

23 Everett Street \#G-24

Cambridge, MA 02138

ananda@law.harvard.edu
M. Julia Prats

IESE Business School

Avda. Pearson, 21

08034 Barcelona

SPAIN

JPrats@iese.edu 


\section{Introduction}

Are high performers more likely to become entrepreneurs than low performers? News accounts are filled with anecdotes of talented professionals making it on their own. These accounts emphasize ability as the key trigger for high performers becoming entrepreneurs and the subsequent success of their ventures (Dorfman 1974; Milligan 1985; Kostigen 1990; Phillips 1997). Although casual observations abound, studies that shed light on the following issues are lacking: (1) Are high performers more likely to become entrepreneurs than low performers? (2) Are high performers more likely to survive as entrepreneurs than low performers? (3) Are there differences between determinants of turnover to entrepreneurship and determinants of other turnover? The focus of our investigation is the empirical phenomenon that, among professionals, talent may be an important driver for starting one’s own firm. ${ }^{1}$

To address these questions, we studied turnover data for security analysts for the nineyear period from 1988 through 1996. We matched samples of entrepreneurs and nonentrepreneurs in the same decision-making setting, and thus avoided sample selection bias. Further, having non-entrepreneurs in our data set allowed us to compare the determinants of entrepreneurial turnover to factors that affect other turnover. The availability of detailed individual and firm level data on equity analysts makes this labor market a particularly attractive setting for our analysis. Institutional Investor magazine’s annual All-America analyst rankings divide analysts into stars and non-stars enabling a clear distinction between high and low performers. ${ }^{2}$ Analysts' rankings are externally observable, which ensures that their performance is visible to the market and makes it possible to compile rich data at five levels of analysis: individual, department, firm, sectoral, and macro-economic. Collecting data at these various levels enabled us to control for a large range of potential drivers of turnover. ${ }^{3}$ 
Our multilevel longitudinal data set on equity analysts enables us to address two criticisms commonly leveled against existing empirical research in entrepreneurship-that the analysis is (a) cross-sectional and (b) single-level. Cross-sectional analysis is susceptible to selfselection bias because it under represents individuals that attempt but fail in entrepreneurial pursuits. Longitudinal observations identify more completely the expanse of entrepreneurial initiatives (Evans and Leighton 1989). Data limitations have precluded prior studies from controlling for both individual and situational variables as drivers of the entrepreneurial decision. In particular, the advantage of this paper is that it uses variables that are more directly related to the overall abilities of the potential entrepreneurs.

Whereas we used a number of econometric techniques (discussed later in the paper) to check the robustness of the results, the limitation of our study is that a small percentage of analysts in our sample became entrepreneurs (45 episodes). However, this paper and analysts' data set allow us to better understand the entrepreneurial behavior among knowledge workers, the relationship between workers' talent and their decision to become self-employed and their probability to survive as entrepreneur, as well as the process of business formation among highly-skilled professionals.

By exploring the phenomenon of entrepreneurship within the context of a particular labor market, we contribute to research in entrepreneurship (Knight 1921; Schumpeter 1934; Lucas 1978; Evans and Leighton 1989; Blanchflower and Oswald 1998; Dunn and Holtz-Eakin 2000), talent allocation (Rosen 1981), and labor market competition (Lazear 1986). Finally, we shed light on new venture creation among professionals, a subject that has been explored previously only on related topics for physicians (Headen 1990; Wholey, et al. 1993), accountants (Pennings, et al. 1998), and biotechnology scientists (Zucker, et al. 1998). ${ }^{4}$ 


\section{Related Literature}

Theoretical economic models of entrepreneurial choice have generated a number of predictions. Knight (1921) suggested that the choice between operating a risky firm or working for a riskless wage is influenced by (a) the availability of enough capital to guarantee the factors their fixed remuneration, (b) a willingness to bear uncertainty, and (c) entrepreneurial ability. Based on those suggestions, some theorists have modeled the occupational choice problem under the assumptions of liquidity constraints (Evans and Jovanovic 1989), risk aversion (Kihlstrom and Laffont 1979) and heterogeneous abilities (Lucas 1978; Jovanovic 1982; Holmes and Schmitz 1990; Jovanovic and Nyarko 1996; Lazear 2002; Irigoyen 2002, Nanda and Sorensen 2004). In the last 25 years, these theorists have established a significant body of research on entrepreneurship.

Central to this paper are studies that consider human capital a key factor in predicting occupational choice. More specifically, our empirical study is guided by theoretical models that point to one's level of ability as the sorting mechanism to an individual selecting entrepreneurship (Lucas 1978; Rosen 1981; Rosen 1982; Jovanovic and Nyarko 1996; Irigoyen 2002, Nanda and Sorensen 2004). In his static model of size-distribution of firms, Lucas (1978) developed an equilibrium theory that assumed an allocation of productive factors over managers of different ability so as to maximize output. Lucas characterizes "managerial (or entrepreneurial) technology" by two elements: "variable skill or talent and an element of diminishing returns to scale or to span of control” (Lucas 1978, p. 511). For efficient allocations, he predicts, it will be the most talented only who manage new firms, and other agents under the 
cutoff equilibrium level will remain employees. Similarly, Rosen (1982), in his model on the distribution of earnings, attributes choice of position (as well as skewed differences in earnings) to the latent talent possessed by each person. ${ }^{5}$ He writes, “. . . for efficiency, the scale economy of management inputs requires that the most able personnel be assigned to top level positions in very large firms” (Rosen 1982, p. 313). Jovanovic and Nyarko (1996) use the Stepping Stone Model to discuss the concept of mobility. The Stepping Stone model says that "activities that are informationally "close" will form a ladder, but the safer ones should come first: they are a natural training ground because in such activities, mistakes imply smaller foregone output.”(Jovanovic and Nyarko 1996, p.29). Finally, in his most recent model, Irigoyen (2002) proposes a dynamic model in which the most able individuals will select into entrepreneurship since their youth, whereas people in the middle of the distribution will work for someone else during their early employment and then switch to entrepreneurship. ${ }^{6}$ Zucker et al. (1998) provide empirical support for this prediction. They find that leading researchers establish their companies to capture the rents to their intellectual capital. Summarizing, these models suggest that more talented individuals will become entrepreneurs.

Likewise, there is a long tradition of empirical research in entrepreneurship that explores factors that affect the chances of a firm's survival during the ventures' early years. ${ }^{7}$ Initial economic endowments and financial access are key factors that explain new venture survival (Evans and Jovanovic 1989; Evans and Leighton 1989; Holtz-Eakin, et al. 1994; Dunn and Holtz-Eakin 2000). Other empirical models explore the effect of human capital variables on firm survival. Age (as a proxy for human capital endowment of business founders), years of schooling, years of experience (Evans and Leighton 1989), the founder's social capital (Shane and Stuart, 2002), university degrees (Burke, et al. 2000), prior self-employment experience, 
leadership experience, and parental self-employment experience (Burke, et al. 2000) are positively related to new venture success. However, we are not aware of any study that associates a firm's survival with an individual's talent.

\section{The Data, Variables and Aggregate Statistics}

\subsection{The data set}

"Sell-side" analysts employed by brokerage houses to follow companies in a particular industry sector or investment specialty generate information, such as earnings forecasts and stock recommendations, and detailed research reports on the companies. Sell-side analysts' clients are the buy-side, meaning institutional investors, which include money management firms, mutual funds, hedge funds, and pension funds. Every year in mid-October, Institutional Investor magazine publishes an "All-America Research Team” list that ranks equity analysts by sector at four levels: first, second, third, and runner-up. The editor's letter asks voters to rank the analysts who "have been most helpful to you and your institution in researching U.S. equities over the past twelve months." The identities of the survey respondents and the institutions they work for are kept confidential. Survey respondents give one overall numerical score to every research analyst in each industry sector. The votes are cumulated using weights based on the size of the voting institution. ${ }^{8}$ An analyst can be ranked in more than one sector; however, only a small percentage of analysts achieve rankings in multiple sectors. Some, but not all, star analysts in a given year continue to be ranked in subsequent years. Siconolfi (1992) writes of the exhaustive ranking process that “[t]here aren’t many other jobs in America where peoples’ performances are externally rated so specifically.” 
Because institutional clients make their own buy decisions, institutional investors, as they search for specific pieces of information, value the work of an analyst on all six dimensions. Clients want the analyst to add value to their decision-making process (Brenner 1991). When analysts' clients were asked to rank, in order of importance, the factors that most attributed to a successful security firm, industry knowledge emerged as a solid first, followed by stock selection, written reports, special services, earnings estimates, servicing, quality of sales force, and market making/execution (Institutional Investor 1998). The net result of this exhaustive Institutional Investor ranking process is that the poll is a good representation of where customers find value from research analysts (Siconolfi 1992). Hence, the rankings are a more complete and comprehensive proxy of the analyst's ability than the performance of stock recommendations and/or the analysts' earnings forecast accuracy.

The market recognizes that ranked analysts perform better than their non-ranked counterparts (Stickel 1992). All-American ranked analysts supply more accurate earnings forecasts than other analysts and make recommendations that do not follow the crowd (Stickel 1990; Stickel 1992). Consequently, an Institutional Investor ranking can mean hundreds of thousands of dollars in extra annual pay for analysts (Laderman 1998). ${ }^{9}$

From the annual issues of Institutional Investor magazine’s “All-America Research Team” listings, we identified, for the nine-year period from 1988 through 1996, 3,513 ranked equity analysts (analyst-year combinations) from 62 firms. We focused on the top 24 investment banking firms that employed more than 15 ranked analysts over the nine years covered by the study. These firms accounted for 3,408 ranked analyst names, which was 97 percent of all the analysts ranked during this period. From the annual issues of the Nelson's Directory of Investment Research, published at the end of each calendar year, we identified 6,123 names of 
unranked equity analysts belonging to the top 24 firms. These firms accounted for 38 percent of the equity analysts $(25,053)$ employed in the United States over the period covered by our data. The total sample of 9,531 names (analyst-year combinations) represented 2,602 individual analysts. ${ }^{10}$

Although 36 percent of the analysts in our sample of 24 firms are ranked, relative to the entire security industry this proportion would be much smaller because analysts in smaller firms primarily tend to be unranked. Although our selection approach biases our data in favor of greater representation of ranked analysts, it helps us control for demographic, analyst performance, departmental, firm, sector, and macroeconomic variables because such information is more readily available for the top 24 firms. (Demographic and departmental characteristics are often not available for research boutiques.) By focusing on the top 24 firms, we were able to track individual analysts and identify different types of turnover: (a) moved to entrepreneurship, (b) moved to competitors within the research industry, or (c) moved to companies outside the research industry. We have made the trade-off in favor of richer information for the smaller subset of the analysts belonging to the top 24 firms.

Independent variables are divided into five categories: individual variables; research department variables; firm variables; sector variables; and macroeconomic variables. Summary statistics for the variables used in the subsequent analysis are presented in panels A and B of Table 1.

\subsection{Dependent variables}

By tracking ranked and unranked equity analysts in the subsequent year's Nelson's Directory of Investment Research and Institutional Investor listings and searching during the year the Lexis-Nexis, Institutional Brokers Estimate System (I/B/E/S), and the National 
Association of Security Dealers data bases, we were able to identify, in each year from 1988 through 1996, whether analysts (a) stayed with their original firms, (b) moved to entrepreneurship, (c) moved to competitors within the research industry, or (d) moved to companies outside the research industry. We also identified 362 moves by analysts to other responsibilities within the same firms. Because intra-firm mobility is difficult to distinguish from inter-firm movement, prior research tends to include such moves in turnover figures. Because such moves have complex dynamics (including aspects of promotion, demotion, and job rotation) different from firm exits, we excluded these observations from our data set.

Over the nine-year period, we identified 1,777 total moves among the 9,531 analysts for a turnover rate of 18.6 percent per annum. Of the analysts who moved, 45 made a transition to entrepreneurship, 1,673 represented other turnover (moved to competitors, moved to buy-side, laid off, retired, died, joined the firms they had been covering for years). ${ }^{11}$ There is no discernible time trend in turnover. Summary statistics on mobility of the analysts are given in Table 2.

The variable EntrepreneurialChoice ${ }_{i, t}$ is 1 if analyst $i$ became an entrepreneur during year t, 0 otherwise. Using EntrepreneurialChoice ${ }_{i, t}$ as a dependent variable confounds two different types of non-entrepreneurs: non-entrepreneurs who stayed and non-entrepreneurs who moved. Next, we distinguish between two types of moves: moves to entrepreneurship and other moves. The variable Moves $_{i, t}$ is defined to take the value of "NoMoves ${ }_{i, t}$ " if analyst $i$ did not move during year $t$, "EntrepreneurialMoves ${ }_{i, t}$ " if analyst $i$ became an entrepreneur during year $t$, and "OtherMoves ${ }_{i, t}$ " if the analyst $i$ moved to non entrepreneurial position during year $t .{ }^{12}$ The two dichotomies compare groups "EntrepreneurialMoves $i, t$ " and "OtherMoves ${ }_{i, t}$ " to "NoMoves ${ }_{i, t}$ ", to test the general hypothesis that different types of turnover have different causal antecedents. 
Turnover rate to competitors is 0.5 percent per annum: 0.8 percent per annum (28 out of 3,408) among ranked analysts; 0.3 percent per annum (17 out of 6,123) among non-ranked analysts. Forty-four analysts founded money management firms, hedge funds, and research and advisory companies; one star analyst founded an airline company. All new ventures were established in the areas in which analysts specialized, suggesting that analysts attempt to leverage sector-specific skills in their entrepreneurial ventures. The reasons why only a small percentage of analysts became entrepreneurs can be found in the characteristics of their labor market. $^{13}$

Finally, we introduce the VentureSurvival variable to test whether the probability of the new venture survival differs for high-ability analysts from that of low-ability analysts. VentureSurvival $_{i, t+3}$ is 1 if analyst $i$ moved to self employment during year $t$ and his/her new venture still exists after three years, 0 if analyst $i$ moved to self employment during year $t$ and his/her new venture does not exist after three years.

\section{$\underline{3.3 \quad \text { Individual variables }}$}

We examined a number of individual and contextual variables that are identified to be important in theoretical mobility models and empirical tests (Lucas 1978; Jovanovic 1982; Eccles and Crane 1988; Evans and Leighton 1989; Holmes and Schmitz 1990; Holtz-Eakin, et al. 1994; Blanchflower and Oswald 1998; Dunn and Holtz-Eakin 2000; Irigoyen 2002; Lazear 2002).

We researched issues of Institutional Investor as far back as 1972 (the first year of rankings) to trace the number of years each analyst was ranked. Hence, our sample includes analysts who have never been ranked as well as analysts who have appeared in the Institutional Investor rankings for a quarter of a century. Four hundred and twenty of the 9,531 analysts (4.4 
percent of the data set, 12.3 percent of the 3,408 ranked analysts) were ranked for the first time. On average, analysts in our data set were ranked approximately thrice. Median star tenure was 0 years; 57.2 percent of the analysts have never been ranked. Focusing on ranked analysts only, average star tenure was 7.2 years.

We collected analysts’ demographic and career characteristics (gender and number of years of experience in the industry) by conducting searches on Lexis-Nexis, the National Association of Securities Dealers web database, Institutional Brokers Estimate System, and Dow Jones News. In our sample, 76.5 percent of analysts are male. ${ }^{14}$ On average, an analyst in our sample had 7.62 years of experience, worked at the same firm for 5.27 years, and held 1.59 jobs.

The independent variable AnalystStar ${ }_{i, t}$ is 1 if analyst $i$ is ranked in year $t$.

AnalystStarTenure $_{i, t}$ is the number of years analyst $i$ has been ranked as of the end of year $t$. To distinguish further between high- and low-ability analysts, we introduce another variable.

AnalystAllStar is 1 for analysts who have been stars for at least five years and are currently stars, 0 otherwise. To capture demographic and career characteristics, we define three other variables. AnalystGender $_{i, t}$ is 1 if analyst $i$ is male, 0 if female. AnalystExperience $e_{i, t}$ is the total number of years analyst $i$ has worked as of October $15^{\text {th }}$ of year $t$. AnalystJobs $s_{i, t}$ is the number of careerrelated jobs analyst $i$ has held as of October $15^{\text {th }}$ of year $t^{15}$

\subsection{Research department variables}

The quality of the research department is operationalized according to the Greenwich Associates Institutional Research Services rankings of research departments. Every year, interviews with approximately 3,000 investment professionals are used to produce the rankings of the best research departments. Portfolio managers and buy-side analysts are asked to name their top sources for investment ideas. Buy-side professionals are quizzed about service, 
products, knowledge, and the performance of brokerage houses' sales representatives. ${ }^{16}$

DepartmentQuality ${ }_{i, t}$ is the percentage of institutional clients who rate the brokerage house as having the best ten research department in analyst i's research department in year $t$. An average research department quality was 30.83 .

\section{$\underline{3.5}$ Firm variables}

To estimate firm performance for all the firms in our data set, we developed a profit proxy-the sum of equity and debt underwriting and merger and acquisition fees during the year. From Securities Data Corporation, we collected firms' profit data based on U.S. merger and acquisition fees (based on credit to target and acquirer advisers), U.S. equity underwriting gross spreads (based on credit full to each lead manager), and U.S. debt underwriting gross spread (credit full to each lead manager). These three figures are summed to generate the profit proxy for a firm for a particular year. We calculate the proportion of total profits generated by each of the 24 firms in our data set during a particular year. To estimate change in relative profit performance, we calculate for each firm the proportionate change in this relative profit from one year to the next. On average, relative profit increased during any given year by 25.2 percent; median increase is 3.4 percent per annum. FirmPerformance ${ }_{i, t}$ is the proportional change during the year preceding time $t$ in the ratio of analyst $i$ 's firm profits from equity and debt underwriting and merger and acquisition advisory fees to the total industry profits. ${ }^{17}$ In addition, FirmDummy ${ }_{i, t}$ controls for firm-level variation.

\subsection{Sector variables}

We grouped the sectors in 80 categories according to the Institutional Brokers Estimate System. In cases where an analyst covers more than one sector, the sector was chosen based on the number of firms an analyst tracks in one sector compared to another, as it appeared in the 
Institutional Brokers Estimate System database. An average sector was followed by 137 equity analysts in any given year, although there are wide variations in coverage. SectorSize $e_{i, t}$ is the total number of equity analysts following analyst $i$ 's sector as of year $t$. SectorDummy ${ }_{i, t}$ controls for sector-level variation. ${ }^{18}$

\section{$\underline{3.7 \quad \text { Macroeconomic variables }}$}

We use proportionate change in the S\&P 500 index (as a broad economic indicator) to estimate macroeconomic performance in the years preceding each of the nine years. Our study covers both a period of macroeconomic decline and a period of macroeconomic expansion. On average, during any one year, the S\&P index increased by 11.3 percent. S\&P500Performance, is the proportional change in the S\&P 500 index during the year preceding time $t$.

\section{Models And Results}

\subsection{Stardom and Entrepreneurial Choice}

We estimate the probability of an analyst becoming an entrepreneur as a function of analyst stardom, individual, firm, sector and macroeconomic variables. We use the following probit model specification: ${ }^{19}$

$$
P\left(\text { EntrepreneurialChoice }_{i, t+1}\right)=\alpha+\beta_{1} \text { x AnalystStar }{ }_{i, t}+\beta_{2} \text { x AnalystGender }{ }_{i, t}
$$

$+\beta_{3} \times$ AnalystExperience $_{i, t}+\beta_{4} \times$ AnalystExperience $_{i, t}^{2}+\beta_{5} \times$ AnalystJobs $_{i, t}+\beta_{6} \mathrm{x}$

FirmDummy $_{i, t}+\beta_{7} \mathrm{x}_{\text {SectorDummy }},+, \beta_{8} \times$ YearDummy $_{t}+\varepsilon_{i, t+1}$

Column (1) in Table 3 presents a regression that estimates the probability of becoming an entrepreneur as a function of analyst stardom, individual, firm, sector, and macroeconomic variables. ${ }^{20}$ The regression controls for all firm-specific, sector-specific, and intertemporal variations by using firm, sector, and year dummies in the regressions. AnalystStar has a 
significant positive coefficient $(\mathrm{p}<0.01)$. Being ranked by Institutional Investor magazine increases the probability of becoming an entrepreneur with a marginal effect of 0.7 percent over the mean ( 0.5 percent). Being male increases the probability of becoming an entrepreneur ( $\mathrm{p}<$ 0.05 ) at the mean by 0.5 percent. AnalystExperience and AnalystJobs have insignificant coefficients.

Column (1) of Table 3 conducts a stringent test of the influence of stardom on the probability of analyst turnover by using firm, sector, and year dummies in the regressions. Column (2) estimates the probability of becoming an entrepreneur as a function of analyst stardom, and a variety of department (the quality of the research department), firm (firm performance), sector (sector size), and macroeconomic (macroeconomic performance) variables. The estimating equation for column (2) is (2).

$$
P\left(\text { EntrepreneurialChoice }_{i, t+1}\right)=\alpha+\beta_{1} \times \text { AnalystStar }_{i, t}+\beta_{2} \times \text { AnalystGender }_{i, t}
$$

$+\beta_{3} \mathrm{x}$ AnalystExperience $e_{i, t}+\beta_{4} \mathrm{x}$ AnalystExperience ${ }^{2}{ }_{i, t}+\beta_{5} \mathrm{x}$ AnalystJobs $_{i, t}+\beta_{6} \mathrm{x}$

DepartmentQuality $_{i, t}+\beta_{7}$ FirmPerformance $_{i, t}+\beta_{8} \mathrm{x}$ SectorSize $_{i, t}+\beta_{9} \mathrm{x}$ S\&P500Performance ${ }_{t}+\varepsilon_{i, t+1}$

Results in column (2) of Table 3 for individual variables are; AnalystStar remains positive significant $(\mathrm{p}<0.01)$. The research department variable, DepartmentQuality, is not significant. We also find that firm performance does not significantly influence the probability of analyst turnover to entrepreneurship. The sector variable also does not have a significant coefficient. At the macroeconomic level, we find that the probability of analyst entrepreneurial turnover is not sensitive to the proportional change in the S\&P 500 index. 
Finally, to further distinguish between different analysts’ ability level, we substitute AnalystStar by AnalystAllStar. Analysts who are repeatedly ranked by Institutional Investor magazine are considered all-stars because they are able to sustain their performance over a period of time. This is a stronger test on whether analysts' performance affects their probability of becoming an entrepreneur. Regression results are shown in column (3) of Table 3. AnalystAllStar has a significant positive coefficient $(\mathrm{p}<0.05)$. Hence, established all-star performers tend to have a greater propensity to become self-employed. The predicted probability of exit at the mean is 0.4 percent. Being an all-star increases the probability of turnover to entrepreneurship by 0.6 percent at the mean. The results for other variables remain largely unchanged.

Overall, our results suggest that analysts’ ability and gender (individual factors) influence turnover to entrepreneurship. Entrepreneurship, however, is not driven by situational variables; for example, at the department level by quality, at the firm level by performance, at the sector level by size, or at the macroeconomic level by performance. ${ }^{21}$

Entrepreneurial analysts identified the following categories of motives for their departures: the urge to broaden their account base (strict limitations at the former firms on what clients cover); the desire to put their own stamp on the organization by building a firm based on their values; to obtain the freedom of investment thought (independence from politics of the firm on what stocks to recommend); the chance for the analysts to make more money and capitalize on their talents; the burnout factor of their former research jobs (the long hours, the marketing demands, the travel, the pressure to generate the investment banking deals); and personality conflicts. Some ranked analysts indicate that they left because by achieving a star status, they accomplished the highest honor in the research business and there was no room to grow. A 
number of stars indicated that they decided to become entrepreneurs after evaluating their life accomplishments, with many stating that they reached a point in their lives where they knew if they didn't make the break, they never would and later would regret it.

In supplemental analysis, we also control for relative analyst accuracy, absolute analyst accuracy, and visibility.

Relative Accuracy. We estimated analysts’ average earnings forecast accuracy during the sample period using the same measure of relative forecast accuracy as Hong, Kubik and Solomon (2000) and Hong and Kubik (2003). For each company and quarter that an analyst issued an earnings forecast, we ranked the analyst on forecast accuracy relative to all other analysts from the IBES dataset covering the same company and quarter. When an analyst issued multiple forecasts for the same company-quarter, we selected the latest forecast to estimate forecast accuracy ranking. Percentile ranks (ranging from a low of $0 \%$ for the least accurate analyst to $100 \%$ for the most accurate analyst) were constructed the following:

$$
\text { Percentile Rank } \text { Rijt }=100-\left\{\frac{\text { Rank }_{i j t}-1}{\text { Company Coverage }_{j t}-1}\right\} * 100
$$

where Rank $k_{i j t}$ is analyst j’s forecast accuracy rank for firm i in quarter t, and Company Coverage $_{j t}$ is the number of analysts issuing forecasts for firm i in quarter t. The Percentile Rank estimates are then averaged across firms and quarters covered by the analyst to provide an average measure of an individual's relative forecast accuracy. The IBES data is less complete than the Nelson database. The number of observations drops as we try to match the IBES dataset to the analyst observations. However, when this variable is included in our regressions, it is not statistically significant. 
Absolute Accuracy. We also constructed a measure of the absolute forecast accuracy of an analyst following the Hong, Kubik and Solomon (2000) and Hong and Kubik (2003) methodologies. We measured the analyst's accuracy for a particular firm in a given year by focusing on the absolute difference between her forecast and the actual earning per share number of the firm. The absolute difference was scaled by the stock price. Because analysts follow multiple firms, we aggregated this forecasting accuracy measure across all the firms that an analyst covers. Similar to Hong, Kubik and Solomon (2000) and Hong and Kubik (2003), we aggregate the average forecast errors for all firms for the three previous years compared to doing it for one year because some analysts cover few firms and, therefore, these analysts' measures are noisy if they are done for one year. After including this measure in our regressions, it the absolute accuracy variable is not statically significant.

Visibility. One alternative explanation is that star analysts are more visible and, therefore, exposed to more business opportunities. We focused on press coverage to measure analysts' visibility. All press searches were performed in Factiva, which covers all major wire services, major, national, and regional publications. For each year and for every analyst, we obtained the number of press articles. Examining the effect of the press coverage on entrepreneurial turnover, we find that the relationship is not significant.

We show that an analyst's absolute and relative forecasting ability as well as visibility has no effect on an analyst's decision to start a new firm. The stardom variable might be capturing important dimensions that are significant for entrepreneurship: client service and accessibility, industry knowledge, and the quality of written reports.

In the next section, we examine whether drivers of entrepreneurship turnover are different from factors that determine other movements. 


\section{$\underline{4.2 \text { Stardom and All Moves }}$}

As we mentioned earlier, using EntrepreneurialChoice as a dependent variable confounds two different types of non-entrepreneurs: non-entrepreneurs who stayed and nonentrepreneurs who moved. In this section we conduct the analyses with a different dependent variable: Moves. We assume three nominal outcomes: where "NoMoves" = no turnover, “EntrepreneurialMoves” = turnover to entrepreneurship, and "OtherMoves" = turnover to nonentrepreneurial position. The Moves variable allows us to test whether different types of turnover have different causal antecedents. In Table 4, the estimating equations for columns (1) through (6) are equations (1), (2), (3) of Table 3 respectively with the new dependent variable. ${ }^{22}$

An examination of turnover to entrepreneurship in columns (1) through (3) of Table 4 shows all variables having coefficients similar in significance and magnitude to those in Table 3. However, examining other turnover (to non-entrepreneurial positions) in column (4), we find that AnalystStar has a significant negative coefficient $(\mathrm{p}<0.01)$. Being a star decreases the probability of moving to another firm with a marginal effect of 4.4 percent over the mean (at which predicted exit probability is 13.7 percent). Hence, in contrast with what we found for movements to entrepreneurship, high performers are less likely to move to competitors than low performers. AnalystExperience has a significant negative coefficient $(\mathrm{p}<0.01)$, whereas AnalystJobs has a significant positive coefficient $(\mathrm{p}<0.05)$. Each additional year of experience reduces the analyst's turnover probability by 0.6 percent at the mean. Analysts' past movements determine their current propensity to move. Each additional job that an analyst held in the past increases the analyst's turnover probability by 1.1 percent at the mean. AnalystGender has a 
significant negative coefficient $(\mathrm{p}<0.05)$. Women have a greater propensity than men to exit firms. Being male reduces the probability of turnover to another firm by 1.1 percent at the mean.

In examining other turnover in column (5) of Table 4, the results for individual variables remain largely unchanged from column (4). In contrast with the results for movements to entrepreneurship, the coefficient of DepartmentQuality is negative and significant $(\mathrm{p}<0.01)$, indicating that analysts working in a better department have a lower propensity to exit. A 1 percent increase in the percentage of institutional clients who rate the brokerage house as having one of the best ten research departments reduces the probability of exit at the mean by 0.2 percent. At the firm level, in contrast to entrepreneurial turnover, firm performance significantly influences the probability of analyst turnover. Good investment banking performance by a firm in the preceding year (FirmPerformance) reduces the probability of analyst turnover $(\mathrm{p}<0.05)$. For a 10 percent negative change in the firm performance, the probability of analyst turnover increases by 0.09 percent. Finally, as we found for moves to entrepreneurship, the sector and macroeconomic variables do not have significant coefficients.

Finally, column (6) of Table 4, which presents the regression results of other moves, yields very different results than the self-employed model in column (3) of Table 4. AnalystAllStar has a significant negative coefficient $(\mathrm{p}<0.01)$. Being an all-star reduces the probability of turnover to competitors by 6.6 percent at the mean (14.5 percent). Hence, established all-star performers are more likely to stay with their firms or choose entrepreneurship.

Comparing entrepreneurial turnover with other turnover, we document that there are differences in factors that drive these two different types of mobility. In fact, when characteristics of these two types of turnover are examined, the same variables change signs 
(ability and gender). Situational drivers (department, firm, sector, macro economy) do not drive turnover to entrepreneurship; only ability and gender do. In contrast, situational drivers (department and firm) as well as individual ones (ability, experience, prior mobility, and gender) drive other turnover. Our findings suggest that studies that do not differentiate between different types of mobility might be documenting less precise relationships between drivers of turnover and workers' mobility.

\subsection{The Determinants of New Venture Survival}

We estimate the probability of the new venture survival as a function of the independent variable (performance) and three classes of control variables (demographic factors and macroeconomic factors). We use the following probit model specification: ${ }^{23}$

$$
P\left(\text { VentureSurvival }_{i, t+3}\right)=\quad \alpha+\beta_{1} \times \text { AnalystStar }_{i, t}+\beta_{2} \times \text { AnalystGender }_{i, t}
$$

$+\beta_{3}$ x AnalystExperience $e_{i, t}+\beta_{4} \times$ S\&P500Performance ${ }_{t=0 \rightarrow 3}+\varepsilon_{i, t+3}$

The model in Table 5 presents a regression that estimates the probability of survival in three years as a function of analyst stardom, individual, and macroeconomic variables. The estimated coefficient on Analyst star is positive and significant $(\mathrm{p}<0.05)$. Hence, being ranked by Institutional Investor increases the probability of the venture survival after an analyst becomes an entrepreneur with a marginal effect of 40.5 percent over the mean (45.9 percent). ${ }^{24}$ New ventures found by more capable analysts have a higher probability to survive for three years. ${ }^{25}$ Finally, we find that the greater the expansion of the U.S. economy, the higher the probability of the venture survival after analysts become entrepreneurs. The estimated coefficient for the $S \& P 500$ performance ( $t=0$ to $t+3$ ) variable is positive and significant $(\mathrm{p}<$ 0.01). For a 10 percent proportional positive change in the S\&P 500 index during a particular three-year period, the probability of an analyst's entrepreneurial success increases by 7.0 percent 
over the mean. Overall, our results suggest that analyst's ability and performance of the economy influence venture’s survival.

\section{Summary and Conclusions}

Many economists and social scientist agree that entrepreneurship has become an important phenomenon in our society. However, few studies have examined empirically the entrepreneurial activity in the professional service industries. Furthermore, no empirical studies explore the effects of workers' ability on entrepreneurial activity. In this paper, we examine the effect of workers' ability on (a) probability of their entrepreneurial turnover and (b) subsequent survival of new ventures. We also control for other potential drivers of turnover besides performance at five levels: demographic, departmental, firm, professional specialization, and macroeconomic characteristics. We offer new evidence on the determinants of turnover to entrepreneurship and the factors affecting survival of new ventures in the context of a professional service industry.

Analysis of entrepreneurial efforts from a panel data set of equity research analysts in investment banks over 1988-1996 reveals that star analysts are more likely than non-star analysts to become entrepreneurs. We also find that ventures founded by star analysts have a higher probability to survive in three years than non-star analysts, and the probability of survival is procyclical with the performance of the economy.

Many empirical studies of employee turnover treat all exits from a firm alike. We have found that turnover to entrepreneurship has different dynamics from other turnover. Hence, theoretical models as well as empirical studies of turnover of workers should disentangle the different types of turnover by destination. In contrast to entrepreneurial turnover, we find that 
star analysts are less likely than their non-star counterparts to experience other turnover; more experienced analysts are less likely to exit their firms than less experienced analysts; being male decreases the probability of other turnover; analysts' past movements increase their current propensity to move; the probability of other turnover is greater for lower-rated research departments; and other turnover is anticyclical with the performance of the firm.

This study contributes to several recent lines of research. Our results empirically support Lucas' (1978) theoretical prediction that the relatively more talented workers become entrepreneurs. Furthermore, our findings are consistent with the works of (Zucker, et al. 1998) that leading professionals found companies to earn rents on their intellectual capital. Also, supporting prior studies (Blanchflower and Oswald 1998), we find that being male increases the probability of turnover to entrepreneurship. By exploring the phenomenon of turnover within the context of professionals in the labor market of equity security analysts, the paper also contributes to research in talent allocation (Rosen 1981) and labor market competition (Lazear 1986).

One limitation of this paper is that the sample includes a restricted class of agents, security analysts. Future research conducted in different settings would be helpful to confirm the relationship between ability and entry and exit from entrepreneurship. Comparing the entrepreneurial turnover pattern of equity analysts with the turnover dynamics of engineers, software programmers, money managers, and other professionals could help test the generalization of our conclusions across various professions.

Our findings have implications for the allocation of resources by policy-makers and other institutions promoting entrepreneurial activity. Our findings have implications for human resource practitioners as well. Whereas firms try to minimize turnover to competitors, at the same time, they might be maximizing entrepreneurial turnover. To our knowledge, no study has 
been able to establish what mobility is more damaging to the firm. We believe that it is an important question for future research. 


\section{REFERENCES}

Blanchflower, D. G. and A. J. Oswald. 1998, "What Makes an Entrepreneur," Journal of Labor Economics, 16.1, 26-60.

Brenner, L., 1991, "The Bull and the Bear," United States Banker, January, 25-27.

Burke, A. E., F. R. FitzRoy and M. A. Nolan, 2000, "When Less Is More: Distinguishing between Entrepreneurial Choice and Performance," Oxford Bulletin of Economics \& Statistics, 62, 565-87.

Dorfman, D., 1974, "The Rise of Entrepreneurial Analysts," Institutional Investor, July, 43-106.

Dorfman, J., 1991, "Analysts Devote More Time to Selling as Firms Keep Scorecard on Performance," Wall Street Journal, October 29, C1.

Dunn, T. and D. Holtz-Eakin, 2000, "Financial Capital, Human Capital, and the Transition to Self-Employment: Evidence from Intergenerational Links," Journal of Labor Economics, 18, 282-305.

Eccles, R. G. and D.B. Crane, 1988, Doing Deals, Cambridge, MA: Harvard Business School.

Evans, D. S. and B. Jovanovic, 1989, "An Estimated Model of Entrepreneurial Choice under Liquidity Constraints," Journal of Political Economy, 97. 4, 808-27.

Evans, D. S. and L. Leighton, 1989, "Some Empirical Aspects of Entrepreneurship," The American Economic Review, 79, 519-35.

Foster, A. and M. Rosensweig, 1995, "Learning by Doing and Learning from Others: Human Capital and Technical Change in Agriculture," Journal of Political Economy, 6. 103, 1176-1209.

Greene, W. H., 2000, Econometric Analysis, Upper Saddle River, NJ: Prentice Hall. 
Headen, A. E., 1990, "Wage, Returns to Ownership, and Fee Responses to Physician Supply," The Review of Economics and Statistics, 72.1, 30-37.

Holmes, T. J.and J. A. Schmitz, 1990, "A Theory of Entrepreneurship and Its Application to the Study of Business Transfers," Journal of Political Economy, 982, 265-94.

Holtz-Eakin, D., D. Joulfaian and H. S. Rosen, 1994, "Entrepreneurial Decisions and Liquidity Constraints," The Rand Journal of Economics, 23.2, 340-47.

Hong, H., J. D. Kubik and A. Solomon, 2000, "Security Analysts' Career Concerns and Herding of Earnings Forecasts," RAND Journal of Economics, 31, 121-44.

Hong, H. and J. D. Kubik, 2003, "Analyzing the Analysts: Career Concerns and Biased Earning Forecasts," The Journal of Finance, 58.1, 313-51.

Institutional Investor, 1998, "The 1998 All-America Research Team," Institutional Investor, October, 99-106.

Irigoyen, C., 2002, "Where Do Entrepreneurs Come From?" Working paper, University of Chicago.

Jovanovic, B., 1982, "Selection and the Evolution of Industry," Econometrica, 50, 649-70.

Jovanovic, B. and Y. Nyarko, 1996, "Stepping Stone Mobility," NBER Working Paper \#5651.

Kihlstrom, R. E. and J. Laffont, 1979, "A General Equilibrium Entrepreneurial Theory of Firm Formation Based on Risk Aversion," The Journal of Political Economy, 87.4, 719-48.

King, G. and L. Zeng, 1999, "Estimating Absolute, Relative, and Attributable Risks in CaseControl Studies," Department of Government, Harvard University.

King, G. and L. Zeng, 1999, "Logistic Regression in Rare Events Data," Department of Government Harvard University.

Knight, F., 1921, Risk, Uncertainty and Profit, New York: H H. 
Kostigen, T., 1990, "Captain of Your Own Ship," Investment Dealers' Digest, February, 22-29.

Laderman, J., 1998, "Who Can You Trust? Wall Street's Spin Game," Business Week, October $5,148-56$.

Lazear, E.P., 1986. "Raids and Offer Matching." Research in Labor Economics, Vol. 8A, pp. $141-65$.

Lazear, E. P., 2002, "Entrepreneurship," In NBER Working Paper Series 9109, 2002.

Lucas, R. E., 1978, "On the Size Distribution of Business Firms," Bell Journal of Economics, 9, $508-23$.

Milligan, J. W., 1985, "The Boutiques Are Making It Big," Institutional Investor, November, $175-87$.

Nanda, R. and J. B. Sorensen, 2004, "Labor Mobility and Entrepreneurship," Manuscript.

Pennings, J. M. K. Lee and A. van Wittelloostuijn, 1998, "Human Capital, Social Capital and Firm Dissolution," Academy of Management Journal, 41.4, 425-40.

Phillips, B., 1997, "Free at Last?" Institutional Investor, August, 48-55.

Rosen, S., 1982, "Authority, Control and the Distribution of Earnings," Bell Journal of Economics, 13, 311-23.

Rosen, S., 1981, "The Economics of Superstars," American Economic Review, 75, 845-58.

Schumpeter, J. A., 1934, The Theory of Economic Development, Cambridge, MA: Harvard University Press.

Shane, S. and T. Stuart, 2002, "Organizational Endowment and the Performance of University Start-Ups," Management Science, 48, 154-70.

Siconolfi, M., 1992, "Shearson Research Analysts Finish First on 'All -America Team' for Third Year," The Wall Street Journal, October 13, C18. 
Stickel, S. E., 1990, "Predicting Individual Analyst Earnings Forecast," Journal of Accounting Research, 28, 409-17.

Stickel, S. E., 1992, "Reputation and Performance among Security Analysts," Journal of Finance, 47.5, 1811-36.

Watson, J. and J.E. Everett, 1993, "Defining Small Business Failure," International Small Business Journal, 11.3, 35-48.

Wholey, D. R., J. B. Christianson and S. M. Sanchez, 1993, "The Effect of Physician and Corporate Interests on the Formation of Health Maintenance Organizations," American Journal of Sociology, 99.1, 164-200.

Zucker, L. G., M. R. Darby and M. B. Brewer, 1998, "Intellectual Human Capital and the Birth of U.S. Biotechnology Enterprises," The American Economic Review, 88.1, 209-306.

\section{ENDNOTES}

${ }^{1}$ Throughout the paper we use entrepreneurship, entrepreneurial activity, self-employment or entrepreneurial choice as equivalent expressions. Following Evans and Leighton (1989), the self-employed category includes all sole proprietors, partners, and sole owners of incorporated business.

${ }^{2}$ Hereafter, we use the terms ranked analysts and star analysts interchangeably to refer to analysts ranked by Institutional Investor magazine. 
${ }^{3}$ Following Schumpeter's (1934) holistic perspective on entrepreneurship, we argue that the probability of a professional becoming an entrepreneur and her chances of success are simultaneously influenced by variables at different levels of analysis.

${ }^{4}$ Wholey (1993) studies organization formation among physicians when interests of corporate clients are strong and professional diversity leads professional groups to expand their jurisdiction by organizing. In Headen (1990), the labor and entrepreneurial components of reported physicians' net income are separated in an analysis of input and output market performance. Pennings et al. (1998) examine the effect of human and social capital upon firm dissolution with data from a population of Dutch accounting firms. Finally, Zucker et al. (1998) find that the timing and location of the birth of biotech enterprises is determined primarily by the local number of highly productive 'star' scientists actively publishing genetic sequence discoveries. ${ }^{5}$ Rosen (1981) has emphasized that "the phenomenon of superstars, wherein relatively small numbers of people earn enormous amounts of money and dominate the activity in which they engage” (p. 845) is becoming increasingly important in the modern society, particularly in the worlds of sports, arts, music, literature, medicine, law, consulting, academics, science, show business, and other professions. The combination of both the joint consumption technology and imperfect substitution allows few superstars to command very large markets and large incomes. The model might be interpreted that the individuals of extraordinary ability, superstars, are more likely to set up their own firms and, thus, capture high rewards for their services that they were not able to capture working for someone else.

${ }^{6}$ Following Lucas (1978) and Rosen (1982), Irigoyen (2002) summarizes entrepreneurial activities into two categories: management (human capital intensive) and supervision or coordination (time intensive). More able entrepreneurs in this context are interpreted as better 
managers that also have more effective time. In his model, skills or human capital is defined as knowledge that can be innate or acquired through time.

${ }^{7}$ The definition of survival varies enormously across studies (see Watson and Everett (1993) for a good review), challenging comparability of results across research studies.

${ }^{8}$ For instance, in October 1996, Institutional Investor magazine produced a ranking for each of the 80 equity industry groups and investment specialties. The survey reflected the ratings of around 1,300 customers, representing approximately 68 percent of the 300 largest institutions in the United States, as well as other investment management institutions.

${ }^{9}$ At most investment banks, a position on the All-America Research Team is one of the three most important criteria for determining analyst pay (Dorfman 1991).

${ }^{10}$ We identified 42 analysts whose names changed during the nine-year period, primarily because of the addition or change of last names subsequent to a change in marital status, so as to ensure that they were not double counted.

11 Although we specifically identify analysts’ moves, we have followed analysts that move outside the industry for a year. It is possible that later on they would have moved to selfemployment. However, over the nine years, we are not aware of any such case.

${ }^{12}$ Analysis on what drives each type of move within other moves (moved to competitors, moved to buy-side, laid off, retired, died, joined the firms that they had been covering for years) lies outside the scope of this paper.

${ }^{13}$ A number of studies report that new entrepreneurs are driven by the desire to build some equity. But analysts are able to extract their value from their employers because of the external observability of their performance (stock recommendations, earnings forecasts, and research reports). Some firms succeed in retaining their analysts by allowing them to operate as 
independent franchises within the firm. Analysis of turnover across the 24 firms using firm dummies (regressions are not reported) suggests significant inter-firm differences. We find that analysts from UBS, Montgomery, and Kidder Peabody become entrepreneurs more frequently than do those from DLJ, Lehman Brothers, Merrill Lynch, Salomon Brothers, and Sanford C. Bernstein. Analysts' entrepreneurial activity might depend on the firm's structure and the relationship between the firm and its employees. For example, at DLJ and Sanford C. Bernstein the analysts are treated as entrepreneurs running their own franchises. In fact, these analysts have their own individualized profit and loss statements. The authors would like to thank George Baker and Robert Gibbons for offering this insight.

${ }^{14}$ First, the Census data was used to distinguish analysts' gender. Three hundred and seventy nine analysts' first names are used by both men and women. Thus, we looked up their interviews, press releases, and other available public information to identify the gender of those analysts.

${ }^{15}$ Correlations among the independent and control variables highlight the following relationships. We have age data for only 42 percent of the ranked analysts. For these, age is highly correlated with analyst experience (0.55). AnalystExperience ${ }_{i, t}$ is also highly correlated with analyst firm tenure (0.73). To avoid multicollinearity among independent variables, we use AnalystExperience $e_{i, t}$ as not only a measure of analyst experience but also a proxy for analyst age. ${ }^{16}$ The Greenwich Associates results are based on the total number of responses for each firm given by the survey respondents, thus favoring larger staffs with broader coverage. Departmental size is indeed highly correlated with quality (0.61).

${ }^{17}$ We also collected firm performance data for publicly quoted investment banks by calculating for the prior year change in stock price performance deflated by changes in the Dow Jones 
Security Broker index. Information on stock price performance is available only for public firms (46 percent analyst-year combinations). Therefore, we use the FirmPerformance ${ }_{i, t}$ variable in all subsequent analyses. Using deflated stock price performance instead yields similar regression results although, because stock price performance is available for far fewer observations than is investment banking performance, the predictive power of regressions is lower if it is used as the proxy for relative firm performance.

${ }^{18}$ Industry experts assert that turnover on Wall Street varies with the nature of the sectors analysts cover; some sectors are "hot”, others are not (Institutional Investor 1997, 1998). As sectors become "hot"- i.e. technological breakthrough, deregulation, globalization - the range of opportunities increases for professionals. It becomes easier for analysts to set up their own firms. To test this hypothesis, we calculate the sectors' deflated stock market performance (the proportionate change in the stock price of the sector followed deflated by the S\&P 500 index), which, on average, increases by 1.0 percent during any one year. Information on sector performance is available only for the 76 percent analyst-year combinations. Our findings contradict popular wisdom. We do not find an increase in analysts' entrepreneurial activity when sectors are "hot."

${ }^{19}$ We run a robust cluster probit regression model on the panel data set with individual analysts as clusters. The probit robust cluster model regression is particularly robust to assumptions about within-cluster correlation (Greene 2000). We have tested the alternative specification of random effects for the probit regressions. The results of the two specifications are quite similar. Because there are 45 moves to entrepreneurship among the 9,531 analyst-year observations, we implemented the procedures suggested in King and Zeng (1999a; 1999b) for generating approximately unbiased and lower-variance estimates of logit coefficients (available 
only for logit models) and their variance-covariance matrix by correcting for small samples and rare events. Regression results are similar to the robust cluster probit models (we only report the latter).

${ }^{20}$ The number of observations decreases with the introduction of the analyst demographic variables (AnalystExperience and AnalystJobs). Even after using multiple sources to collect the experience information, analyst experience and analyst job data were available for 8,112 analystyear combinations (85 percent). Thus, to properly test whether analyst stardom has an effect on analysts' mobility, we rerun models in columns (1) through (2) of Table 3 without the AnalystExperience and AnalystJobs variables. The new regressions have similar results to the respective models in Table 3.

${ }^{21}$ Previous studies have found that the wealth of the agent affects the probability of becoming an entrepreneur. Wealth would be positive related to riskier decisions such the one of becoming an entrepreneur. However, other studies did not find that correlation. Indeed, in their study on Indian farmers, Foster and Rosensweig (1995) find that change from one crop to a riskier crop could not be explained by wealth effects. Instead, it is explained by their ability of dealing with external markets. Although, our model does not include variables that capture the financial position of the analyst (because there is no information available on the personal wealth of analysts), we believe that the decision of becoming an entrepreneur in a talent based occupation is closer to the idea of mastering the environment instead of triggered by the comfort of a wealthy position. New ventures in a professional setting do not require great investments; it requires a great deal of personal confidence and client/market understanding ${ }^{22}$ A nominal dependent variable can be analyzed via multinomial logistic regression. Whereas recent results on simulation of multinormal integrals have made the estimation of the 
multinomial probit more feasible, the computational problems still persist. Although there are theoretical differences between logit and probit methodologies, probit and logit yield results that are essentially indistinguishable from each other, and the choice of one over the other appears to make virtually no differences in practice (Greene 2000). We find that the estimates from the binary regression are close to those from the multinomial logit model. Thus, we use a probit model to estimate our equations with the reference group being analysts who did not move. ${ }^{23}$ We find appropriate to use a probit model instead of a hazard rate model given the way we have defined the survival variable. The hazard rate is the conditional likelihood that firm failure occurs at duration time $t$, given that it has not occurred in the duration interval $(0, \mathrm{t})$. In contrast, a probit model considers the likelihood that firm failure occurs during the study period (ignoring the duration of the interval). In other words, the probit model considers whether the firm will fail during the study period, rather than when the firm will fail. We are interested on the probability of survival of the firm three years after founding. ${ }^{24}$ There were no acquisitions of new ventures by other companies. All exits of new ventures in our study include the discontinuation of ventures, an indicator of business failure.

${ }^{25}$ Selection effect mechanisms may be driving this result. That is, stars are in a position to select more promising projects that had a priori higher chances to survive independent of analyst's ability per se. Further, high ability analysts may leverage their industry contacts to attract talent to the new venture (traders, analysts, and salesmen) as well as clients. For instance, Dorfman (1974) reports "When Andrew Zunser, a top rated insurance analysts, decided to set up his own firm, he checked with his major accounts and 90 percent of them agreed to go along with him if he went out on his own, with the remaining 10 percent not closing the doors.” 
Table 1. Descriptive Statistics of Entrepreneurial Turnover Dataset

\begin{tabular}{|c|c|c|c|c|c|}
\hline \multicolumn{6}{|c|}{ A. Variables } \\
\hline Variable & $\begin{array}{c}\text { Number of } \\
\text { observations }\end{array}$ & Mean & $\begin{array}{l}\text { Standard } \\
\text { deviation }\end{array}$ & Minimum & Maximum \\
\hline \multicolumn{6}{|l|}{ Probability of becoming an entrepreneur } \\
\hline EntrepreneurialChoice & 9531 & 0.005 & 0.069 & 0 & 1 \\
\hline \multicolumn{6}{|l|}{ Probability of moving } \\
\hline EntrepreneurialMoves $^{\mathrm{a}}$ & 7799 & 0.006 & 0.076 & 0 & 1 \\
\hline OtherMoves $^{\mathrm{b}}$ & 9486 & 0.183 & 0.386 & 0 & 1 \\
\hline \multicolumn{6}{|l|}{ Analyst variables } \\
\hline \multicolumn{6}{|l|}{ - Stardom variables } \\
\hline AnalystStar & 9531 & 0.358 & 0.479 & 0 & 1 \\
\hline AnalystAllStar & 9531 & 0.210 & 0.407 & 0 & 1 \\
\hline \multicolumn{6}{|l|}{ - Demographic \& career variables } \\
\hline AnalystGender & 9531 & 0.765 & 0.424 & 0 & 1 \\
\hline AnalystExperience & 8112 & 7.625 & 5.980 & 0.003 & 57.823 \\
\hline AnalystJobs & 8112 & 1.585 & 0.855 & 1 & 6 \\
\hline \multicolumn{6}{|l|}{ Research department variables } \\
\hline DepartmentQuality & 9531 & 30.832 & 15.810 & 0 & 58 \\
\hline \multicolumn{6}{|l|}{ Firm variables } \\
\hline FirmDummy & 9531 & - & - & 1 & 24 \\
\hline FirmPerformance & 9037 & 0.252 & 1.201 & -1.000 & 14.250 \\
\hline \multicolumn{6}{|l|}{ Sector variables } \\
\hline SectorDummy & 9531 & - & - & 1 & 80 \\
\hline SectorSize & 9531 & 136.813 & 85.427 & 1 & 492 \\
\hline \multicolumn{6}{|c|}{ Security industry \& macroeconomic performance } \\
\hline S\&P500Performance & 9531 & 0.113 & 0.131 & -0.091 & 0.289 \\
\hline YearDummy & 9531 & - & - & 1 & 9 \\
\hline
\end{tabular}

\begin{tabular}{|c|c|c|c|c|c|c|}
\hline \multicolumn{7}{|c|}{ B. New Venture Survival Variables } \\
\hline Class & Variable & $\begin{array}{c}\text { Number of } \\
\text { observations }\end{array}$ & Mean & $\begin{array}{r}\text { Standard } \\
\text { deviation }\end{array}$ & Minimum & Maximum \\
\hline \multicolumn{7}{|c|}{ Analyst variables } \\
\hline \multicolumn{7}{|c|}{ - Stardom variables } \\
\hline & & 45 & 0.622 & 0.490 & 0 & 1 \\
\hline \multicolumn{7}{|c|}{ - Demographic variables } \\
\hline & & 45 & 0.933 & 0.252 & 0 & 1 \\
\hline & & 45 & 8.609 & 6.205 & 0.764 & 24.600 \\
\hline \multicolumn{7}{|c|}{ Macroeconomic performance variables } \\
\hline & ince $(t=0$ to $t=+3)$ & 45 & 0.584 & 0.358 & 0.101 & 1.208 \\
\hline
\end{tabular}

\footnotetext{
${ }^{\mathrm{a}}$ Excludes other moves

${ }^{\mathrm{b}}$ Excludes moves to entrepreneurship
} 
Table 2. Stardom and Mobility of Analysts

\begin{tabular}{|c|c|c|c|c|c|c|c|c|c|c|c|c|c|c|}
\hline \multirow[b]{2}{*}{$\underset{\nu}{\stackrel{\Xi}{\Xi}}$} & \multirow[b]{2}{*}{ 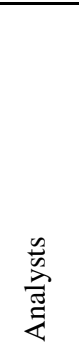 } & \multirow[b]{2}{*}{ 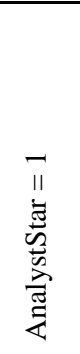 } & \multicolumn{4}{|c|}{ EntrepreneurialMoves } & \multicolumn{4}{|c|}{ OtherMoves } & \multicolumn{4}{|c|}{ MovesAll } \\
\hline & & & 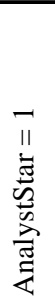 & 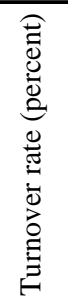 & 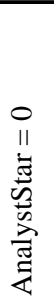 & 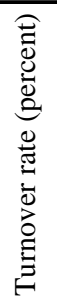 & 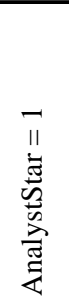 & 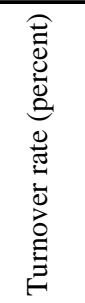 & 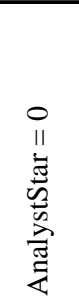 & 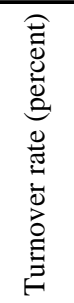 & 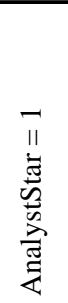 & 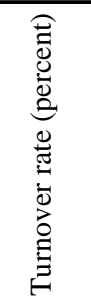 & 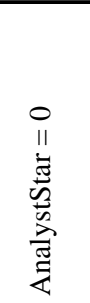 & 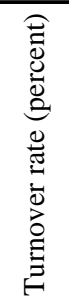 \\
\hline 1988 & 1008 & 392 & 7 & 1.8 & 1 & 0.2 & 39 & 9.9 & 113 & 18.3 & 46 & 11.7 & 114 & 18.5 \\
\hline 1989 & 984 & 385 & 2 & 0.5 & 1 & 0.2 & 28 & 7.3 & 175 & 29.2 & 30 & 7.8 & 176 & 29.4 \\
\hline 1990 & 894 & 369 & 3 & 0.8 & 2 & 0.4 & 40 & 10.8 & 124 & 23.6 & 43 & 11.7 & 126 & 24.0 \\
\hline 1991 & 925 & 386 & 4 & 1.0 & 3 & 0.6 & 41 & 10.6 & 98 & 18.2 & 45 & 11.7 & 101 & 18.7 \\
\hline 1992 & 986 & 393 & 1 & 0.3 & 2 & 0.3 & 38 & 9.7 & 104 & 17.5 & 39 & 9.9 & 106 & 17.9 \\
\hline 1993 & 1097 & 435 & 2 & 0.5 & 0 & 0.0 & 44 & 10.1 & 144 & 21.8 & 46 & 10.6 & 144 & 21.8 \\
\hline 1994 & 1168 & 430 & 4 & 0.9 & 3 & 0.4 & 62 & 14.4 & 201 & 27.2 & 66 & 15.3 & 204 & 27.6 \\
\hline 1995 & 1159 & 306 & 1 & 0.3 & 3 & 0.4 & 33 & 10.8 & 180 & 21.1 & 34 & 11.1 & 183 & 21.5 \\
\hline 1996 & 1310 & 312 & 4 & 1.3 & 2 & 0.2 & 32 & 10.3 & 236 & 23.6 & 36 & 11.5 & 238 & 23.8 \\
\hline Total & 9531 & 3408 & 28 & $0.8^{\mathrm{a}}$ & 17 & 0.3 & 357 & $10.5^{\mathrm{a}}$ & 1375 & 22.5 & 385 & $11.3^{\mathrm{a}}$ & 1392 & 22.7 \\
\hline
\end{tabular}

${ }^{\mathrm{a}}$ AnalystStar $=1$ and AnalystStar $=0$ columns have different means at .05 level of significance. 
Table 3. The Effect of Stardom on the Probability of Moving to Entrepreneurship

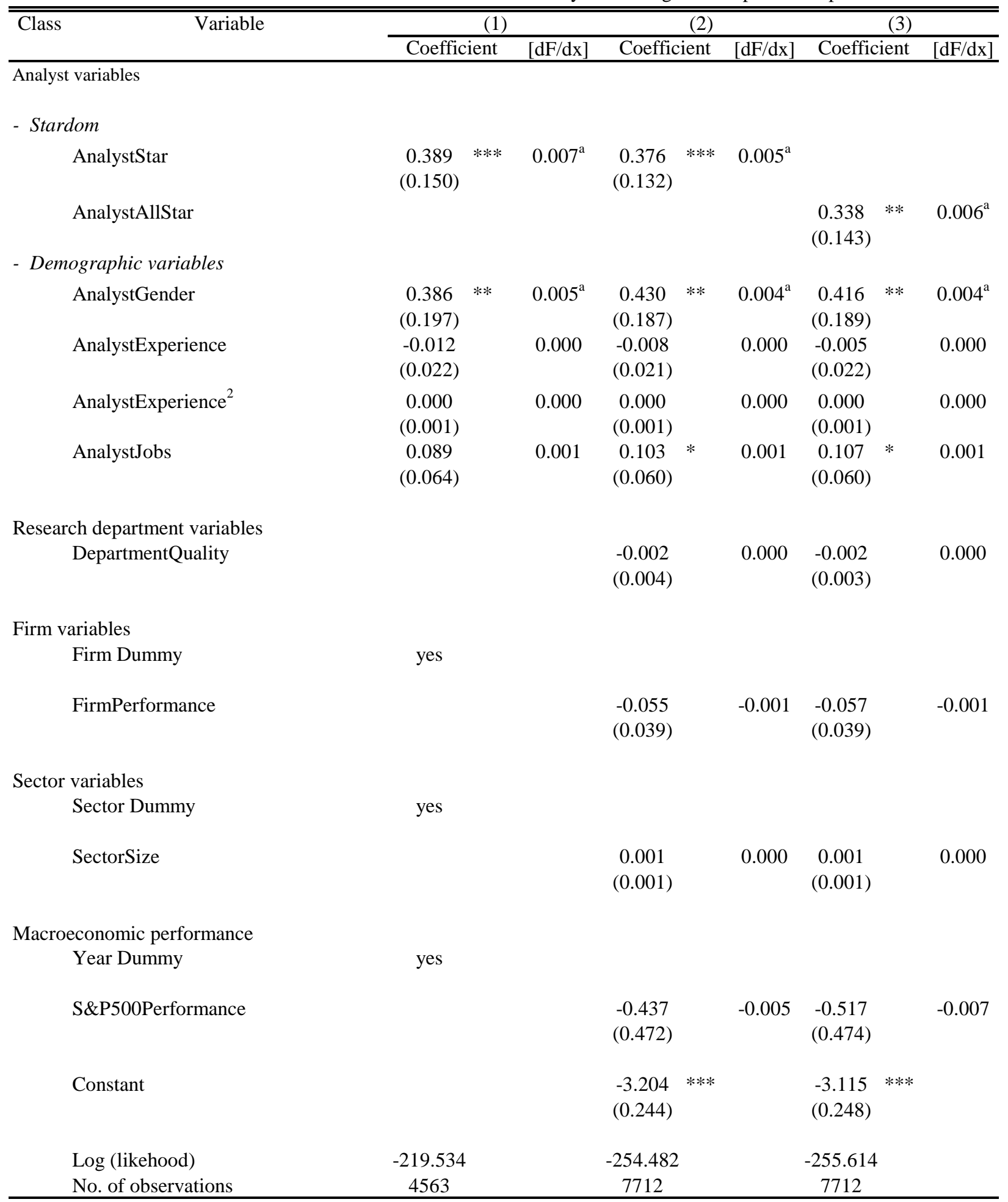

*statistically significant at the .10 level; ** at the .05 level; *** at the .01 level.

Note.- Robust standard errors are in parentheses and are adjusted for intra-analyst correlation of the errors.

${ }^{a} \mathrm{dF} / \mathrm{dx}$ is for discrete change of the dummy variable from 0 to 1 . 
Table 4. The Effect of Stardom on Analysts' Transition Probability

\begin{tabular}{|c|c|c|c|c|c|c|c|c|c|c|c|c|c|c|c|c|c|c|}
\hline \multirow[b]{4}{*}{ Variable } & \multicolumn{18}{|c|}{ "Dependent variable } \\
\hline & \multicolumn{9}{|c|}{ EntrepreneurialMoves } & \multicolumn{9}{|c|}{ OtherMoves } \\
\hline & \multicolumn{3}{|c|}{$(1)$} & \multicolumn{3}{|c|}{$(2)$} & \multicolumn{3}{|c|}{ (3) } & \multicolumn{3}{|c|}{ (4) } & \multicolumn{3}{|c|}{ (5) } & \multicolumn{3}{|c|}{ (6) } \\
\hline & Coeffici & cient & {$[\mathrm{dF} / \mathrm{dx}]$} & Coeffic & cient & {$[\mathrm{dF} / \mathrm{dx}]$} & Coeffic & cient & {$[\mathrm{dF} / \mathrm{dx}]$} & Coeffici & ient & {$[\mathrm{dF} / \mathrm{dx}]$} & Coeffici & ient & {$[\mathrm{dF} / \mathrm{dx}]$} & Coefficient & & {$[\mathrm{dF} / \mathrm{dx}]$} \\
\hline \multicolumn{19}{|l|}{ Analyst variables } \\
\hline \multicolumn{19}{|l|}{ - Stardom } \\
\hline AnalystStar & $\begin{array}{c}0.388 \\
(0.151)\end{array}$ & $* * *$ & $0.008^{\mathrm{a}}$ & $\begin{array}{c}0.362 \\
(0.134)\end{array}$ & $* * *$ & $0.006^{\mathrm{a}}$ & & & & $\begin{array}{l}-0.207 \\
(0.043)\end{array}$ & $* * *$ & $-0.044^{\mathrm{a}}$ & $\begin{array}{l}-0.223 \\
(0.042)\end{array}$ & $* * *$ & $-0.050^{\mathrm{a}}$ & & & \\
\hline AnalystAllStar & & & & & & & $\begin{array}{c}0.319 \\
(0.144)\end{array}$ & $* *$ & $0.006^{\mathrm{a}}$ & & & & & & & $\begin{array}{c}-0.316 \\
(0.052)\end{array}$ & $* * *$ & $-0.066^{\circ}$ \\
\hline \multicolumn{19}{|l|}{ - Demographic variables } \\
\hline AnalystGender & $\begin{array}{c}0.380 \\
(0.202)\end{array}$ & * & $0.005^{\mathrm{a}}$ & $\begin{array}{c}0.419 \\
(0.191)\end{array}$ & $* *$ & $0.005^{\mathrm{a}}$ & $\begin{array}{c}0.407 \\
(0.193)\end{array}$ & $* *$ & $0.005^{\mathrm{a}}$ & $\begin{array}{l}-0.197 \\
(0.044)\end{array}$ & $* * *$ & $-0.046^{\mathrm{a}}$ & $\begin{array}{l}-0.178 \\
(0.042)\end{array}$ & $* * *$ & $-0.043^{\mathrm{a}}$ & $\begin{array}{l}-0.169 \\
(0.042)\end{array}$ & $* * *$ & $-0.040^{\circ}$ \\
\hline AnalystExperience & $\begin{array}{l}-0.014 \\
(0.022)\end{array}$ & & 0.000 & $\begin{array}{l}-0.010 \\
(0.022)\end{array}$ & & 0.000 & $\begin{array}{l}-0.007 \\
(0.022)\end{array}$ & & 0.000 & $\begin{array}{l}-0.030 \\
(0.008)\end{array}$ & $* * *$ & -0.007 & $\begin{array}{c}-0.031 \\
(0.007)\end{array}$ & $* * *$ & -0.007 & $\begin{array}{l}-0.030 \\
(0.007)\end{array}$ & $* * *$ & -0.007 \\
\hline AnalystExperience $^{2}$ & $\begin{array}{c}0.000 \\
(0.001)\end{array}$ & & 0.000 & $\begin{array}{c}0.000 \\
(0.001)\end{array}$ & & 0.000 & $\begin{array}{c}0.000 \\
(0.001)\end{array}$ & & 0.000 & $\begin{array}{l}0.001 \\
(0.000)\end{array}$ & $* *$ & 0.000 & $\begin{array}{c}0.001 \\
(0.000)\end{array}$ & $* *$ & 0.000 & $\begin{array}{c}0.001 \\
(0.000)\end{array}$ & $* *$ & 0.000 \\
\hline AnalystJobs & $\begin{array}{c}0.095 \\
(0.065)\end{array}$ & & 0.001 & $\begin{array}{c}0.112 \\
(0.061)\end{array}$ & * & 0.002 & $\begin{array}{c}0.117 \\
(0.060)\end{array}$ & * & 0.002 & $\begin{array}{c}0.051 \\
(0.021)\end{array}$ & $* *$ & 0.011 & $\begin{array}{c}0.086 \\
(0.020)\end{array}$ & $* * *$ & 0.020 & $\begin{array}{c}0.083 \\
(0.021)\end{array}$ & $* * *$ & 0.019 \\
\hline \multicolumn{19}{|l|}{ Research department variables } \\
\hline DepartmentQuality & & & & $\begin{array}{l}-0.004 \\
(0.004)\end{array}$ & & 0.000 & $\begin{array}{l}-0.003 \\
(0.004)\end{array}$ & & 0.000 & & & & $\begin{array}{c}-0.009 \\
(0.001)\end{array}$ & $* * *$ & -0.002 & $\begin{array}{l}-0.009 \\
(0.001)\end{array}$ & $* * *$ & -0.002 \\
\hline \multicolumn{19}{|l|}{ Firm variables } \\
\hline Firm Dummy & yes & & & & & & & & & yes & & & & & & & & \\
\hline FirmPerformance & & & & $\begin{array}{c}-0.062 \\
(0.039)\end{array}$ & & -0.001 & $\begin{array}{l}-0.064 \\
(0.039)\end{array}$ & & -0.001 & & & & $\begin{array}{c}-0.041 \\
(0.016)\end{array}$ & $* *$ & -0.009 & $\begin{array}{c}-0.040 \\
(0.016)\end{array}$ & $* *$ & -0.009 \\
\hline \multicolumn{19}{|l|}{ Sector variables } \\
\hline Sector Dummy & yes & & & & & & & & & yes & & & & & & & & \\
\hline SectorSize*100 & & & & $\begin{array}{c}0.076 \\
(0.060)\end{array}$ & & 0.001 & $\begin{array}{c}0.066 \\
(0.061)\end{array}$ & & 0.001 & & & & $\begin{array}{l}-0.013 \\
(0.021)\end{array}$ & & -0.003 & $\begin{array}{l}-0.014 \\
(0.021)\end{array}$ & & -0.003 \\
\hline \multicolumn{18}{|l|}{ Macroeconomic performance } & \\
\hline S\&P500Performance & & & & $\begin{array}{l}-0.457 \\
(0.478)\end{array}$ & & -0.007 & $\begin{array}{l}-0.529 \\
(0.480)\end{array}$ & & -0.008 & & & & $\begin{array}{l}-0.061 \\
(0.138)\end{array}$ & & -0.014 & $\begin{array}{l}-0.029 \\
(0.136)\end{array}$ & & -0.007 \\
\hline Constant & & & & $\begin{array}{l}-3.094 \\
(0.248)\end{array}$ & $* * *$ & & $\begin{array}{l}-3.011 \\
(0.253)\end{array}$ & $* * *$ & & & & & $\begin{array}{l}-0.442 \\
(0.075)\end{array}$ & $* * *$ & & $\begin{array}{l}-0.472 \\
(0.075)\end{array}$ & $* * *$ & \\
\hline Log (likehood) & -212.89 & & & -247.94 & & & -249.02 & & & -3219.56 & & & -3181.64 & & & -3176.57 & & \\
\hline No. of observations & 3893 & & & 6531 & & & 6531 & & & 8032 & & & 7669 & & & 7669 & & \\
\hline
\end{tabular}

Note.- Robust standard errors are in parentheses and are adjusted for intra-analyst correlation of the errors.

${ }^{a} \mathrm{dF} / \mathrm{dx}$ is for discrete change of the dummy variable from 0 to 1 . 
Table 5. The Effect of Stardom on the Probability of Firm Survival

\begin{tabular}{|c|c|c|c|}
\hline Variable & \multicolumn{2}{|c|}{ Coefficient } & $\mathrm{dF} / \mathrm{dx}$ \\
\hline \multicolumn{4}{|l|}{$\begin{array}{l}\text { Analyst variables } \\
\text { - Stardom }\end{array}$} \\
\hline AnalystStar & $\begin{array}{c}1.094 \\
(0.508)\end{array}$ & $* *$ & $0.405^{\mathrm{a}}$ \\
\hline \multicolumn{4}{|l|}{ - Demographic variables } \\
\hline AnalystGender & $\begin{array}{c}0.313 \\
(0.740)\end{array}$ & & $0.121^{\mathrm{a}}$ \\
\hline AnalystExperience & $\begin{array}{l}-0.006 \\
(0.031)\end{array}$ & & -0.002 \\
\hline \multicolumn{4}{|l|}{ Macroeconomic performance } \\
\hline S\&P500Performance ( $\mathrm{t}=0$ to $\mathrm{t}=+3$ ) & $\begin{array}{c}1.751 \\
(0.670)\end{array}$ & $* * *$ & 0.695 \\
\hline Constant & $\begin{array}{l}-2.048 \\
(1.114)\end{array}$ & $*$ & \\
\hline Log Likelihood & \multicolumn{3}{|c|}{-25.311} \\
\hline Number of observations & \multicolumn{3}{|c|}{45} \\
\hline
\end{tabular}

*statistically significant at the .10 level; ** at the .05 level; *** at the .01 level.

${ }^{a} \mathrm{dF} / \mathrm{dx}$ is the marginal increase due to a given variable controlling for every other variables. 